\title{
Studies on Metmyoglobin Reducing Enzyme Systems in the Muscle of Blue White Dolphin-II Purification and Some Physico-chemical Properties of Ferrimyoglobin Reductase
}

\author{
Takashi MATSUI, ${ }^{* 1}$ Chiaki ShimzU, ${ }^{* 2}$ and Fumio MatsuURA ${ }^{* 1}$
}

(Received April 19, 1975)

\begin{abstract}
Using a procedure essentially according to HEGEsH's isolation method for human ferrihemoglobin reductase (FerriHb R), its corresponding enzyme, tentatively named ferrimyoglobin reductase (FerriMb R), was isolated in a highly pure state from the skeletal muscle of blue white dolphin, and compared physico-chemically with the FerriHb $R$ isolated from the erythrocytes of the same animal. The sedimentation and diffusion coefficients were $3.70 \mathrm{~S}$ and $6.67 \times 10^{-7} \mathrm{~cm}^{2} \mathrm{sec}^{-1}$, respectively, for the FerriHb R, and $3,91 \mathrm{~S}$ and $5.85 \times 10^{-7} \mathrm{~cm}^{2} \mathrm{sec}^{-1}$, for the FerriMb $R$. The molecular weights, $M_{s, D}$ of the FerriHb $R$ and FerriMb $R$ were 51,000 and 65,000 , and $M_{e}$ were 61,000 and 64,000 , respectively. Their pH-mobility curves also differed from each other. These two reductases were, however, hardly distinguishable from each other, both in possessing an isoelectric point near $\mathrm{pH} 5$ and in exhibiting absorption maxima at 279 and $407 \mathrm{~nm}$.
\end{abstract}

As the enzymes participating in metmyoglobin (MMb) reduction in the mammalian erythrocytes, diaphorase, methemoglobin reductase, and ferrihemoglobin reductase (FerriHb R) have already been isolated. ${ }^{1-3)}$ In the preceding paper, ${ }^{4)}$ we reported the isolation and characterization of diaphorase from the dolphin muscle. On the other hand, SHImzu et al. have isolated metmyoglobin reductase, an enzyme corresponding to methemoglobin reductase, from the same source. ${ }^{3)}$

This time we searched for the enzyme corresponding to erythrocyte FerriHb $R$ in the dolphin muscle, and succeeded in its isolation by employing HEGESH's method for human FerriHb R. The enzyme obtained, tentatively named ferrimyoglobin reductase (FerriMb $R$ ), was analyzed for physico-chemical properties and compared with those of FerriHb $\mathbf{R}$ isolated from the erythrocytes of the same animal.

\section{Materials and Methods}

Materials The blood and skeletal muscle used were obtained from a live blue white dolphin, Stenella caeruleo-alba, caught at Huto Bay in Shizuoka Pref. Immediately after quick transportation to our laboratory with ice, red cells were separated by centrifugation,

${ }^{* 1}$ Lab. of Marine Biochem., Fac. of Agr., The Univ. of Tokyo, Bunkyo-ku, Tokyo (烃居 隆 - 松浦 文雄：東大费学部)

*2 Fisheries Lab., Fac. of Agr., The Univ. of Tokyo, Shizuoka Pref. (清水千秋：東大農学部附属水磁実 験所) 
washed several times with saline, and kept frozen below $-20^{\circ} \mathrm{C}$ until used. Muscle blocks were provided and similarly kept frozen. The substrate pigments and other reagents were the same as discribed in the previous paper. ${ }^{4}$

\section{Analytical methods}

Enzyme activity The assay was performed by the method of HeGEsh et al. ${ }^{61}$ with slight modifications. The reaction mixture contained $0.1 \mathrm{ml}$ of $15 \mathrm{mM} \mathrm{MMb}, 0.1 \mathrm{ml}$ of $3 \mathrm{~mm}$ ferrocyanide, $1.5 \mathrm{~m} l$ of $0.2 \mathrm{M} \mathrm{CH}_{3} \mathrm{COONa}-\mathrm{CH}_{3} \mathrm{COOH}(\mathrm{pH} 5.2), 0.1 \mathrm{~m} l$ of enzyme solution, $1.1 \mathrm{~m} l$ of water, and $0.1 \mathrm{~m} l$ of $15 \mathrm{mM} \mathrm{NADH}_{2}$ in a total volume of $3 \mathrm{~m} l$. The reaction was started by addition of $\mathrm{NADH}_{2}$ and the reduction of $\mathrm{MMb}$ was measured by the increase of absorbance at $582 \mathrm{~nm}$ with a Hitachi recording spectrophotometer model 124. One enzyme unit $(\mathrm{U})$ was defined here as the activity reducing $1 \mu$ mole of substrate per min.

Ultracentrifugation Ultracentrifugal analyses were performed with a Hitachi UCA-1 analytical ultracentrifuge at $12^{\circ} \mathrm{C}$. The protein solution to be applied was previously dialyzed at $4^{\circ} \mathrm{C}$ against $0.2 \mu \mathrm{Na}_{2} \mathrm{HPO}_{4}-\mathrm{NaH}_{2} \mathrm{PO}_{4}(\mathrm{pH} 7.0)$ containing $0.18 \mathrm{M} \mathrm{NaCl}$. Sedimentation and diffusion runs were carried out at 60,000 and $12,400 \mathrm{rpm}$, respectively. Molecular weight determinations by the sedimentation equilibrium method were conducted using the same machine at $9,800 \mathrm{rpm}$.

Electrophoresis Electrophoretic analyses were performed with a Hitachi Tiselius electrophoresis apparatus model D under a constant current of $5 \mathrm{~mA}$ at $4^{\circ} \mathrm{C}$. A $1.3 \mathrm{ml}$ cell, and Miller and Golder's buffers ${ }^{7)}(0.2 \mu, \mathrm{pH} 5.5$ to 8.5$)$ were used.

Spectrophotometry A Hitachi recording spectrophotometer model 124 was employed. In calculation of the specific activity of both enzymes, the protein concentration as determined by the biuret method was used.

\section{Results and Discussion}

Purification of FerriHb R The method of Hegesh et al. was adopted with several modifications as follows. All the operations were conducted around $4^{\circ} \mathrm{C}$.

Extract To the frozen red cells was added two volumes of cold water and the mixture was adjusted to $\mathrm{pH}$ 7.0. The lyzate was centrifuged and the clear red supernatant was diluted with 5 volumes of cold water and adjusted again to $\mathrm{pH} 7.0$.

$D E A E$-cellulose adsorption The DEAE-cellulose (200 $\mathrm{g}$ on dry basis per litre of wet red cells) pre-equilibrated with $5 \mathrm{mM} \mathrm{Na} \mathrm{NPO}_{4}-\mathrm{KH}_{2} \mathrm{PO}_{4}(\mathrm{pH} 7.0)$ was added batchwise to the above extract and the mixture was left standing for $30 \mathrm{~min}$ under sufficient stirring. The DEAE-cellulose was collected and washed with the same buffer until the washing was colorless. The protein was eluted from the DEAE-cellulose with $50 \mathrm{mM}$ citrate buffer (pH 5.5) containing $60 \mathrm{~mm} \mathrm{KCl}$. To the eluate, solid ammonium sulfate was added up to $100 \%$ saturation. The precipitates formed were collected by filtration, dissolved in a 
small volume of $20 \mathrm{mM} \mathrm{CH}_{3} \mathrm{COONa}-\mathrm{CH}_{3} \mathrm{COOH}$ (pH 5.2) containing $15 \mathrm{mM} \mathrm{KCl}$, and dialyzed overnight against the same buffer. By this treatment, the hemoglobin present in the extract was for the most part eliminated.

CM-cellulose column chromatography The dialyzed solution was applied onto a column $(5 \times 60 \mathrm{~cm})$ of $\mathrm{CM}$-cellulose which was pre-equilibrated with $3.75 \mathrm{mM} \mathrm{CH}_{3} \mathrm{COONa}^{-}$ $\mathrm{CH}_{3} \mathrm{COOH}$ ( $\mathrm{pH}$ 5.2) containing $15 \mathrm{mM} \mathrm{KCl}$. The adsorbed protein was eluted stepwise with the above acetate buffer containing $\mathrm{KCl}$ at $15,65,115$, and $165 \mathrm{~mm}$, as indicated by arrows in Fig. 1. The active fractions as indicated by arrows were combined and saturated with ammonium sulfate. The precipitates obtained were collected and dissolved in $0.05 \mathrm{M} \mathrm{Na}_{2} \mathrm{HPO}_{4}-\mathrm{KH}_{2} \mathrm{PO}_{4}(\mathrm{pH} 7.0$ ) and dialyzed against the same buffer.

Sephadex G-100 gel filtration The dialyzed solution was passed through a Sephadex G-100 column $(2.5 \times 100 \mathrm{~cm})$ pre-equilibrated with the above phosphate buffer. Fig. 2 shows a typical elution profile of the gel filtration. The peak in respect of $\mathrm{MMb}$ reducing activity appeared after the peak in respect of the absorbance at $280 \mathrm{~nm}$, both peaks partly

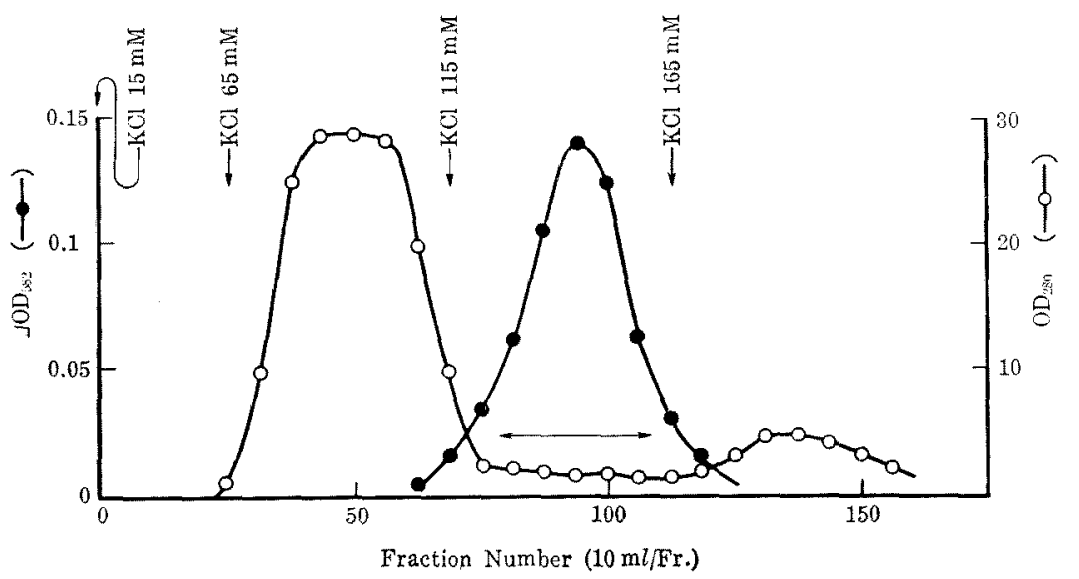

Fig. 1. Purification of dolphin erythrocyte FerriHb R by CM-cellulose column chromatography. Fractions shown by arrows were combined and further purified.

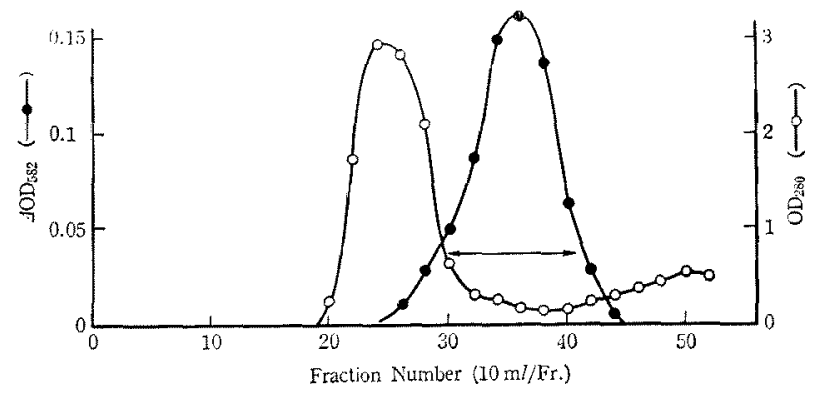

Fig. 2. Purification of FerriHb R by Sephadex G-100 gel filtration. Fractions shown by arrows were combined and further purified. 


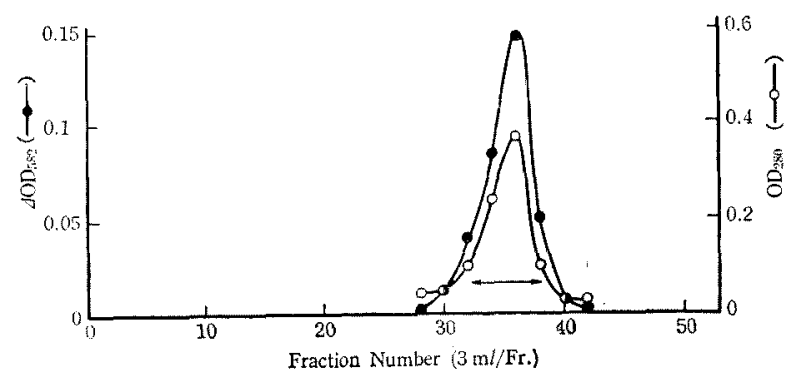

Fig. 3. Purification of FerriHb R by the second Sephadex G-100 gel filtration. Fractions shown by arrows were combined and analyzed.

overlapping each other. The active fractions as indicated by arrows were combined and subjected again to the same gel filtration. As seen in Fig. 3, both peaks coincided satisfactorily this time. The active fractions as shown by arrows were combined, concentrated by ultrafiltration using a collodion bag, and stored at $-20^{\circ} \mathrm{C}$ until subjected to the following analyses.

Purification of FerriMb R After the preliminary examinations, essentially the same procedure as that for FerriHb $R$ was adopted for purification of FerriMb $R$. The frozen dolphin muscle was thawed, minced, and homogenized with 5 volumes of cold water for $2 \mathrm{~min}$ with a blender. The homogenate was centrifuged at $8,000 \times \mathrm{g}$ for $15 \mathrm{~min}$ and the clear extract obtained was adjusted to $\mathrm{pH} 7.0$ with $1 \mathrm{~N} \mathrm{NaOH}$. The solution was subjected to DEAE-cellulose adsorption, CM-cellulose column chromatography, and Sephadex G-100 gel filtration in the same way as described for purification of the FerriHb R. Figs. 4,5 , and 6 show typical chromatogram or gel filtration patterns at these steps. The FerriMb R solution thus obtained was concentrated by ultrafiltration and stored at $-20^{\circ} \mathrm{C}$

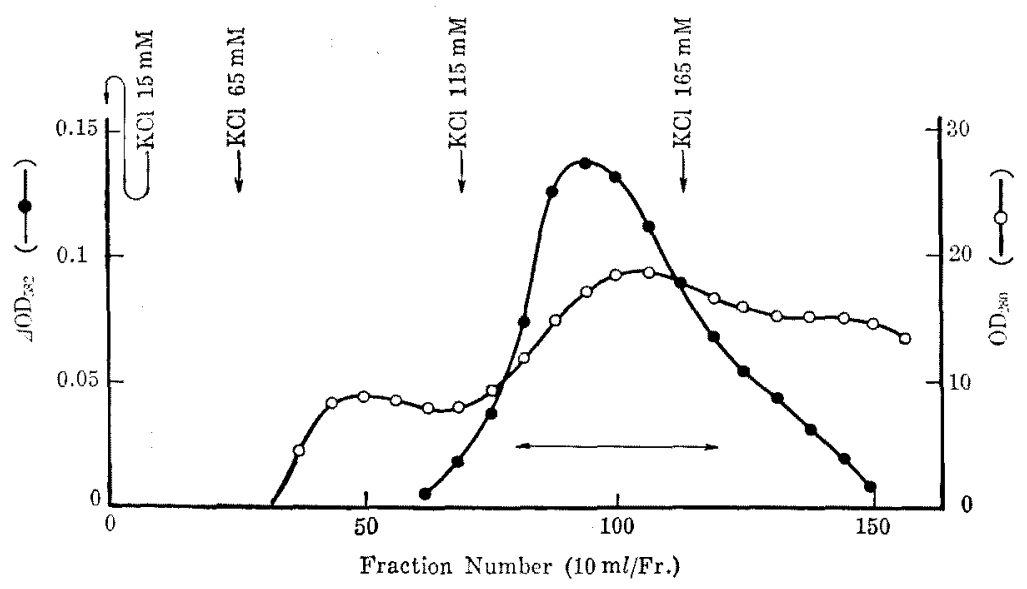

Fig. 4. Purification of FerriMb $\mathbf{R}$ by $\mathrm{CM}$-cellulose column chromatography. Fractions shown by arrows were combined and further purified. 


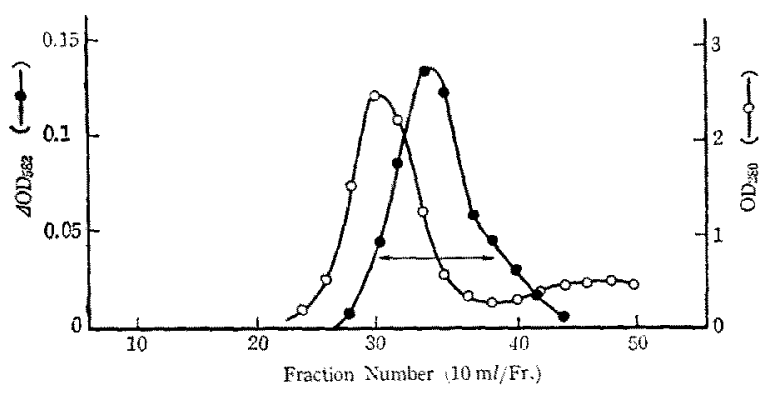

Fig. 5. Purification of FerriMb $R$ by Sephadex G-100 gel filtration. Fractions shown by arrows were combined and further purified.

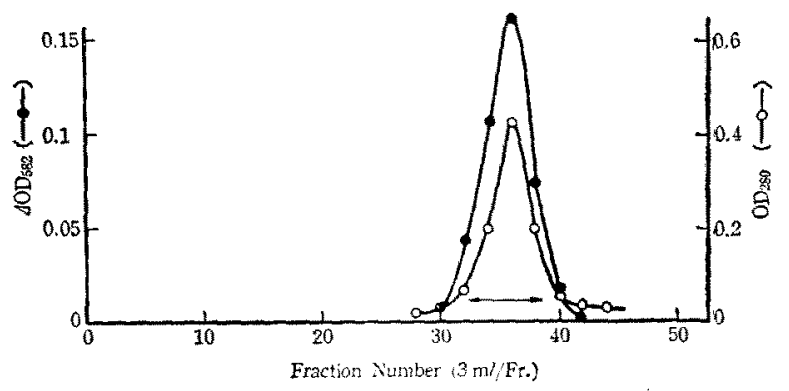

Fig. 6. Purification of FerriMb R by second Sephadex G-100 gel filtration. Fractions shown by arrows were combined and analyzed.

Table 1. Purification of FerriHb R

\begin{tabular}{lccc}
\hline \multicolumn{1}{c}{ Purification steps } & $\begin{array}{c}\text { Total activity* } \\
\text { (U) }\end{array}$ & $\begin{array}{c}\text { Specific activity* } \\
\text { (U/mg protein) }\end{array}$ & $\begin{array}{c}\text { Yield } \\
(\%)\end{array}$ \\
\hline Hemolyzed solution & 31 & 0.00014 & 100 \\
DEAE-cellulose adsorption & 248 & 0.11 & 801 \\
CM-cellulose column & 259 & 2.22 & 836 \\
$\quad$ chromatography & 110 & 4.59 & 356 \\
\hline Sephadex G-100 gel filtration & & &
\end{tabular}

* MMb reducing activity was used.

Table 2. Purification of Ferrimb R

\begin{tabular}{lccc}
\hline \multicolumn{1}{c}{ Purification steps } & $\begin{array}{c}\text { Total activity* } \\
\text { (U) }\end{array}$ & $\begin{array}{c}\text { Specific activity* } \\
\text { (U/mg protein) }\end{array}$ & $\begin{array}{c}\text { Yield } \\
(\%)\end{array}$ \\
\hline Water extract & 2,300 & 0.0165 & 100 \\
DEAE-cellulose adsorption & 632 & 0.070 & 27 \\
CM-cellulose column & 164 & 1.54 & 7 \\
$\quad$ chromatography & 128 & 3.84 & 6 \\
\hline
\end{tabular}

* MMb reducing activity was used. 
until analyzed.

In Tables 1 and 2 are summarized the processes of purification including the changes in total and specific $\mathrm{MMb}$ reducing activities for both reductases. The specific activity of the FerriHb R finally obtained was about 30,000 times as high as that of the hemolyzate. A considerable increase in its total activity after DEAE-cellulose adsorption, seems to suggest the presence of some inhibitor or the substance disturbing the activity assay in the hemolyzate. On the other hand, the specific activity of the FerriMb R was 230 times as high as that of the aqueous extract. The specific activities of both enzymes did not differ so widely. The yield of FerriHb $\mathrm{R}$ was approximately $10 \mathrm{mg}$ per litre of wet red cells, while that of FerriMb R $10 \mathrm{mg}$ per $\mathrm{kg}$ of minced muscle.

Table 3. Physical properties of purified FerriHb $\mathrm{R}$ and FerriMb $\mathbf{R}$

\begin{tabular}{|c|c|c|c|}
\hline & & FerriHb R & FerriMb R \\
\hline Sedimentation coeff. & $\mathrm{s}_{20, \mathrm{~W}}(\mathrm{~S})$ & 3.70 & 3.91 \\
\hline Diffusion coeff. & $\mathrm{D}_{20, \mathrm{w}}\left(\times 10^{-7} \mathrm{~cm}^{2} \mathrm{sec}^{-1}\right)$ & 6.67 & 5.85 \\
\hline Molecular weight & $\mathbf{M}_{\mathrm{S}, \mathrm{D}}$ & 51,000 & 65,000 \\
\hline " " " & $\mathrm{M}_{\mathrm{e}}$ & 61,000 & 64,000 \\
\hline
\end{tabular}

The enzymes here obtained from the erythrocytes and the muscle of dolphin exhibited a single symmetrical peak in both sedimentation and diffusion patterns, indicating an apparent homogeneity. In Table 3 are summarized some physical properties of both enzymes. Sedimentation coefficients of the FerriHb R and FerriMb R were determined to be 3.70 and $3.91 \mathrm{~S}$, respectively. Their diffusion coefficients were 6.67 and $5.85 \times 10^{-7} \mathrm{~cm}^{2} \mathrm{sec}^{-1}$, respectively. On the basis of those sedimentation and diffusion coefficients, the molecular weights of dolphin FerriHb R and FerriMb R were calculated to be 51,000 and 65,000, respectively. On the other hand, the values of 61,000 and 64,000 were obtained by the sedimentation equilibrium method for the FerriHb R and FerriMb R, respectively. Thus, the molecular weights of both enzymes seem to be somewhat different from each other. In this connection, SUGITA et al. ${ }^{8}$ have reported a sedimentation coefficient of $2.77 \mathrm{~S}$ and a molecular weight of 28,000 for human FerriHb R. Hence, there seems to be a marked difference between the two enzymes from dolphin and human erythrocytes.

Both enzymes of dolphin behaved homogeneously in Tiselius electrophoresis over the $\mathrm{pH}$ range covered. As shown in Fig. 7, their $\mathrm{pH}$-mobility curves clearly differed from each other. However, their isoelectric points were both near $\mathrm{pH} 5$. SUGITA et al. ${ }^{8)}$ have reported a value of $\mathrm{pH} 6.2$ for human FerriHb R.

As given in Fig. 8, the absorption spectra of both dolphin enzymes were very similar, showing a large maximum at $279 \mathrm{~nm}$ and a small and dull maximum at $407 \mathrm{~nm}$. These spectra are hardly distinguishable from that of human FerriHb $\mathrm{R}^{8)}$ The specific extinction, $E_{279 \mathrm{~nm}}^{1 \%}$, was caluculated to be 11.6 and 10.6 for dolphin FerriHb R and FerriMb R, respectively. 


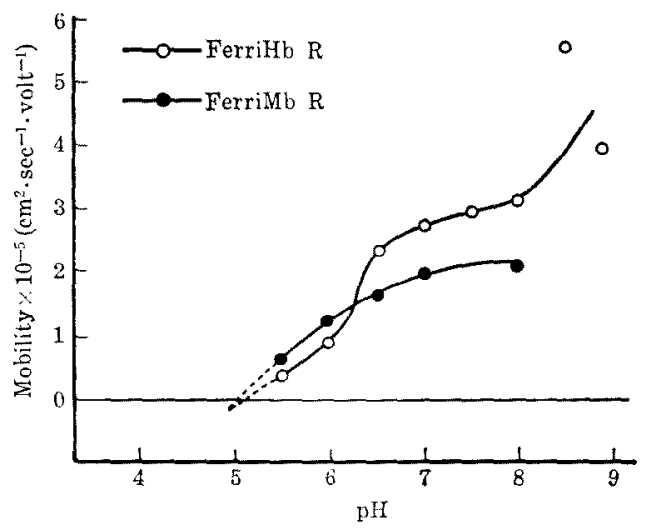

Fig. 7. pH-Mobility curves of dolphin FerriHb $\mathbf{R}$ and FerriMb R.

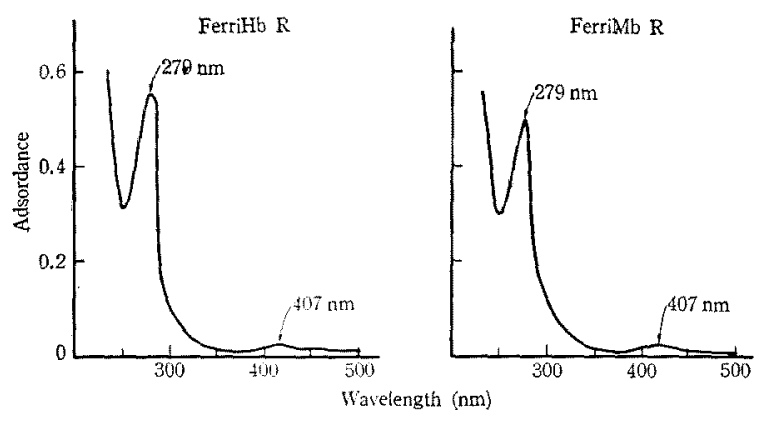

Fig. 8. Absorption spectra of dolphin FerriHb R and FerriMb R.

The two enzymes obtained from the different origins of dolphin are by no means an identical enzyme. Their resemblance in various physico-chemical properties, however, might indicate the presence of organ specificity in one and the same enzyme. On the basis of the results obtained in the present investigation, it could be concluded that metmyoglobin reductase, diaphorase, and FerriMb $\mathrm{R}$ at least are participated in the reduction of $\mathrm{MMb}$ in the muscle.

This work was supported in part by a grant from the Ministry of Education.

\section{References}

1) E. M. Scort and J. C. MCGraw: J. Biol. Chem., 237, 249-252 (1962).

2) C. Shimezu and F. Matsuura: Agr. Biol. Chem., 32, 587-592 (1968).

3) E. Hegesh and M. Avron: Biochim. Biophys. Acta, 146, 91-101 (1967).

4) T. Matsui, C. Shimizu, and F. Matsuura: This Bull, 41, 761-769 (1975).

5) C. Shimzu and F. Matsuura: Agr. Biol. Chem., 35, 468-475 (1971).

6) E. Hegesh and M. Avron: Biochim. Biophys. Acta, 146, 397-408 (1967).

7) G. L. Millar and R. H. Golder: Arch. Biochem., 29, 420-427 (1950).

8) Y. Sugita, S. Nomura, and Y. Yoneyama: J. Biol. Chem., 246, $6072-6078$ (1971). 